\title{
Pengolahan Air Bersih di Panti Asuhan Aisyiyah Cabang Koto Tangah Kota Padang
}

\author{
Femi Earnestly ${ }^{1}$, Muchlisinalahuddin ${ }^{2}$, Weldri Fernando ${ }^{3}$, Kit Nada ${ }^{4}$, Helga Yermadona*5 \\ 1,2,4,5 Program Studi Teknik Mesin Fakultas Teknik, Universitas Muhammadiyah Sumatera Barat \\ ${ }^{3}$ Program Studi Teknik Sipil Fakultas Teknik, Universitas Muhammadiyah Sumatera Barat \\ *e-mail: helga.umsb@gmail.com ${ }^{5}$
}

\begin{abstract}
Groundwater is a water source used by the Aisyiyah Orphanage, Koto Tangah Branch, Padang City for daily needs such as: ablution, washing, bathing and latrines. Unfortunately, the problem with the well water in this orphanage is the low water quality with physical characteristics cloudy and smelly, and cause reddish yellow spots on the walls and bathroom floors which are predicted to be due to excessive levels of iron (Fe) and manganese (Mn) in the water. From the above problems, a solution is needed to discover to help managing the water in the orphanage, in the form of an effort to empower partners through increasing knowledge about the types of water purification and photos of installing water filters that will treat the water in this orphanage. The activities carried out were socialization of natural and artificial purification methods, videos of making water treatment equipment that less suitable for clean water, and distributing questionnaires at the beginning and end of the socialization, where there was an increase in partner knowledge about clean water treatment from $22 \%$ to $64.62 \%$.
\end{abstract}

Keywords: Clean Water Treatment, Orphanage

\begin{abstract}
Abstrak
Air tanah merupakan sumber air yang digunakan oleh Panti Asuhan Aisyiyah Cabang Koto Tangah Kota Padang untuk keperluan sehari-hari seperti: wudhu, cuci, mandi dan kakus. Sayangnya, masalah air sumur di panti asuhan ini adalah air kualitas rendah dengan ciri-ciri fisik tampak keruh dan berbau, serta menimbulkan bercak kuning kemerahan pada dinding dan lantai kamar mandi yang diprediksi akibat kadar besi (Fe) dan mangan (Mn) yang berlebih pada air tersebut. Dari permasalahan diatas, maka diperlukan solusi untuk membantu pengelolaan air di Panti Asuhan tersebut, berupa usaha pemberdayaan mitra melalui peningkatan pengetahuan tentang jenis-jenis penjernihan air dan foto-foto pemasangan filter air akan mengolah air di panti asuhan ini. Kegiatan yang dilakukan adalah sosialisasi tentang metode penjernihan secara alami dan buatan, video pembuatan alat pengolahan air kurang layak menjadi air bersih, dan melakukan penyebaran kuisioner awal dan akhir sosialisasi, dimana terjadi peningkatan pengetahuan mitra tentang pengolahan air bersih dari $22 \%$ menjadi 64,62\%.
\end{abstract}

Kata kunci: Pengolahan air bersih, Panti Asuhan

\section{PENDAHULUAN}

Panti Asuhan Aisyiyah Cabang Koto Tangah terletak di jalan Adinegoro No.37A Muara Penjalinan Kelurahan Pasie Nan Tigo Kecamatan Koto Tangah Kota Padang, yang lokasinya \pm 13 km dari Pantai Pasir Jambak. Peta lokasi Panti ini dapat dilihat pada Gambar 1 berikut ini: 


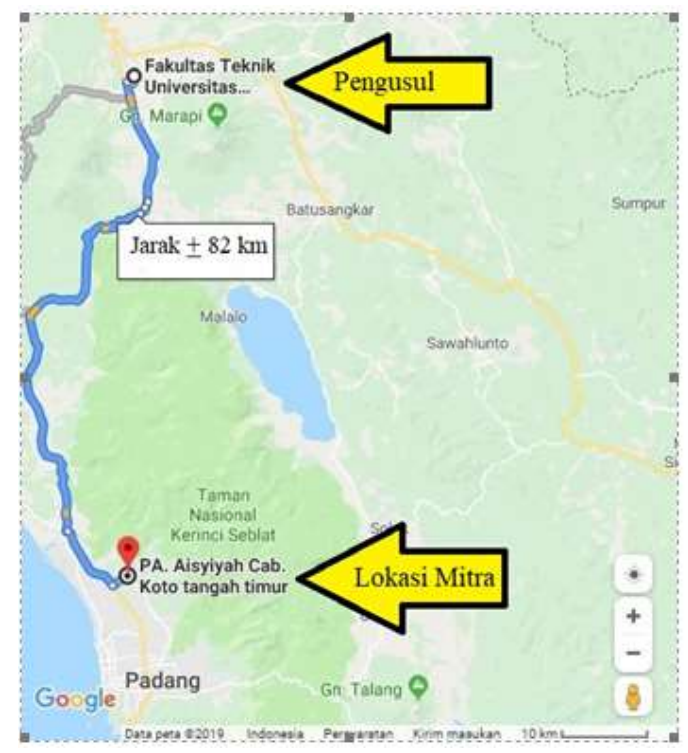

Gambar 1. Peta Lokasi Mitra Panti Asuhan Aisyiyah Cabang Koto Tangah

Berdasarkan survei awal di lokasi, panti asuhan ini dipimpin oleh ibu Hj. Rafidah Yuda, BA didirikan tahun 1963 dengan jumlah anak perempuan di panti asuhan sebanyak 35 orang sampai sekarang masih tetap berupaya melaksanakan pemberdayaan bagi anak terlantar dan miskin (Annisa, 2017). Beliau menjelaskan bahwa anak-anak panti asuhan berasal dari berbagai daerah dan usia yang terbagi atas tingkat pendidikan SD, SMP/MTsN, dan SMA/SMK/MAN. Air bersih tersebut harus memenuhi persyaratan yang tertuang di dalam Peraturan Menteri Kesehatan No. 32 tahun 201 sebanyak 60 liter per orang per hari(Indonesia, 2017).

Pada masa New Normal, penerapan Indikator Perilaku Hidup Bersih dan Sehat salah satunya mencuci tangan dengan air bersih mengalir dan sabun dapat menjaga dan memelihara kesehatan serta berperan aktif untuk mewujudkan masyarakat sehat (RI, 2014), serta mencegah penyebaran Covid-19. Penelitian menunjukkan bahwa mencuci tangan dengan air bersih mengalir dan sabun lebih lebih efektif dibandingkan menggunakan handsanitizer (Nakoe, S Lalu, \& Mohamad, 2020).

Panti Asuhan Aisyiyah ini mempunyai dua sumur yang digunakan sebagai sumber air MCK. Karena lokasinya yang dekat dengan Pantai Pasir Jambak, air sumur di panti asuhan ini berkualitas rendah (air tampak keruh dan berbau), terlihat pada Gambar 2 berikut ini:

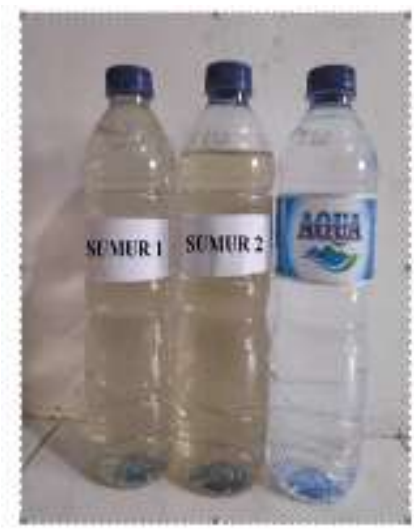

Gambar 2. Perbandingan kondisi air sumur 1 dan 2 di Panti Asuhan Aisyiyah Cabang Koto Tangah dengan air mineral kemasan 
Berdasarkan pengamatan visual, maka kondisi air sumur Panti Asuhan Aisyiyah Cabang Koto Tangah dapat dilihat pada Tabel 1 berikut ini:

Tabel 1. Kondisi visual air sumur dibandingkan dengan standar baku Permenkes No 32 tahun 2017

\begin{tabular}{ccccc}
\hline No & Parameter & $\begin{array}{c}\text { Sumur 1 } \\
\text { (sumur bor) }\end{array}$ & $\begin{array}{c}\text { Sumur 1 } \\
\text { (sumur bor) }\end{array}$ & $\begin{array}{c}\text { Standar Baku } \\
\text { Mutu (maksimum) }\end{array}$ \\
\hline 1 & Kekeruhan & Keruh & Keruh & 25 NTU \\
2 & Warna & Kekuningan & Kenuningan & 50 TCU \\
3 & Rasa & Sedikit pahit, berasa besi & Sedikit pahit, berasa besi & Tidak berasa \\
4 & Bau & Menyengat & Menyengat & Tidak Berbau \\
\hline
\end{tabular}

Banyak unsur logam yang terlarut dalam air sumur seperti kalsium, magnesium, sodium, kalium, bikarbinat, sulfat, kholride, nitrat, derajat keasaman $(\mathrm{pH})$, besi $(\mathrm{Fe})$ dan mangan $(\mathrm{Mn})$ (Sitompul, 2018).

Penelitian Kusumaningrum, et.al menyatakan bahwa kandungan besi didalam air sumur dapat menimbulkan gangguan kesehatan, bau kurang enak, menyebabkan warna kuning pada dinding bak kamar mandi serta bercak-bercak kuning pada pakaian (Kusumaningrum \& Nurhayati, 2016). Berdasarkan pengamatan visual pada dinding dan lantai kamar mandi Panti Asuhan tersebut terdapat banyak bercak warna kuning kemerahan yang mengikuti pola aliran air akibat kadar besi dan mangan dalam air sumur, seperti terlihat pada Gambar 3 berikut ini:
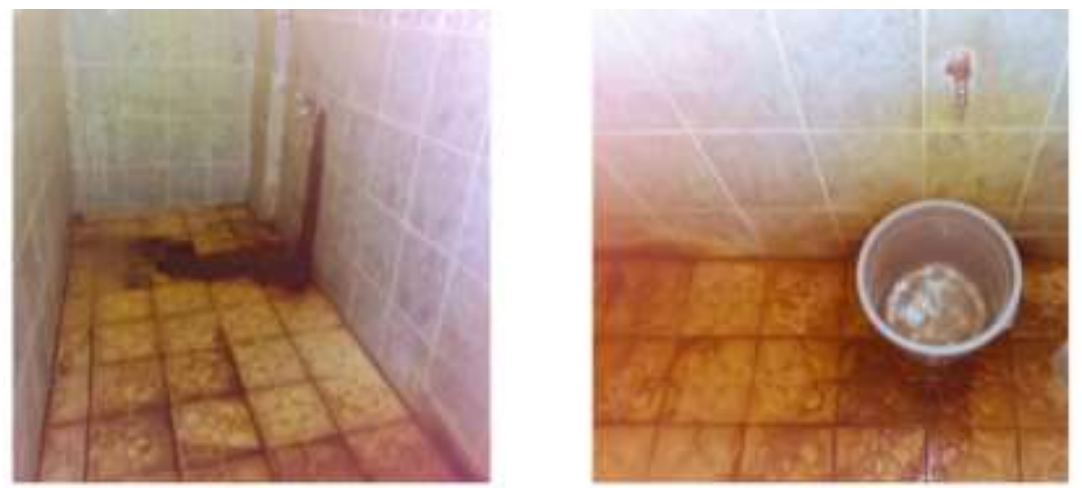

Gambar 3. Bercak Warna Kuning Kemerahan Pada Kamar Mandi Panti Asuhan yang mengikuti Pola Aliran Air Berkadar Besi (Fe) dan Mangan (Mn) Dalam Air Sumur

Pengujian kadar $\mathrm{pH}$ dan kadar $\mathrm{NaCl}$ dinyatakan bahwa ada beberapa sampel ditempat Pasie Nan Tigo masih mempunyai kualitas air dibawah standar yang ditetapkan MENKES RI dalam bentuk Keputusan Nomor 492/Menkes/Per/IV /2010 (Yunike, Erna Juita, \& Farida, 2016).

Masalah prioritas yang perlu diselesaikan yaitu masalah air bersih yang bersumber dari air sumur berkualitas rendah, menyebabkan masalah gatal-gatal pada kulit anak-anak panti asuhan dan menyebabkan bercak-bercak kuning pada pakaian putih seragam sekolah dan penerapan indokator PHBS (Perilaku Hidup Bersih dan Sehat) pada kondisi New Normal (RI, 2014) Sehingga masalah air sumur berkualitas rendah ini perlu dicarikan solusinya melalui kegiatan PPM.

Hasil penelitian tentang kualitas air telah dilakukan pada tahun 2018 di sekitar kampus UM Sumbar tentang kualitas air tanah analisa suhu, $\mathrm{pH}$, kandungan logam besi, amoniak dan klorida pada sumber air tanah dimana kampus UMSB berada pada Kelurahan Pasie Nan Tigo yang lokasinya dekat dengan mitra (Earnestly, 2018a) (Earnestly, 2018b). 


\section{METODE}

\subsection{Lokasi Pengabdian}

Lokasi Pengabdian adalah Panti Asuhan Putri Aisyiyah Cabang Koto Tangan Kota Padang Propinsi Sumatera Barat.

\subsection{Alat dan Bahan}

Alat yang digunakan unyuk membuat pengolahan air di Panti Asuhan yaitu pipa PVC, besi tempat meletakkan alat penjernihan air, sedangkan bahan yang digunakan pasir, kerikil, arang tempurung kelapa, dimana skem alat digambarkan pada gambar 4 dibawah ini.

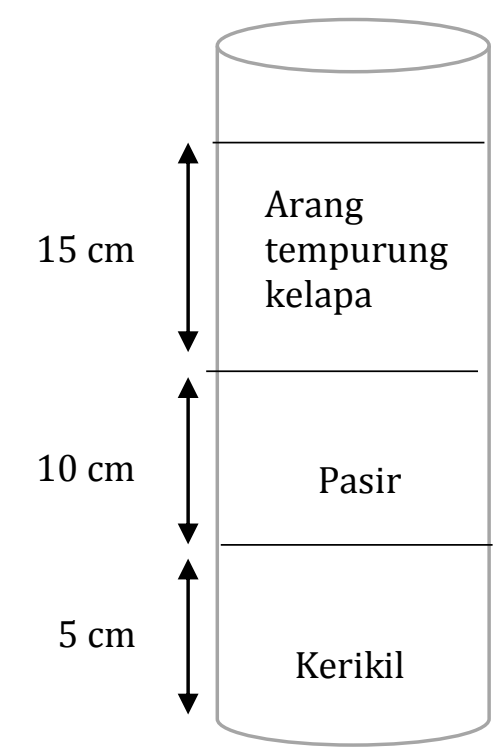

Gambar 4. Bahan Penjernih Air dan Skema Alat

\subsection{Metoda Pelaksanaan Pengabdian pada Masyarakat}

1. Kegiatan Pra Sosialisasi, pada tahap ini tim pengabdian berdiskusi dengan Ketua Panti Asuhan tentang pelaksanaan kegiatan sosialisasi, dimana akan dilakukan sosialisasi.

2. Pembagian angket/kuisioner awal untuk mengetahui pengetahuan awal mitra terhadap materi penjernihan iar

3. Kegiatan Sosialisasi, pemaparan materi tentang: (a) jenis-jenis penjernih dan penyaring air baik secara alami maupun buatan dan (b) pencegahan Covid-19 lebih efektif dengan mencuci tangan pakai air bersih yang mengalir dan sabun dibanding handsanitizer. Pemaparan materi dilakukan dengan mematuhi protokol kesehatan Covid-19, sehingga mencegah penyebaran Covid-19 di daerah tersebut.

4. Penyebaran kuisioner akhir (post-test) setelah pemaparan materi.

\section{HASIL DAN PEMBAHASAN}

\section{Kegiatan Pra Sosialisasi}

Pada tahap ini, tim pelaksana pengabdian menjelaskan dan berkoordinasi dengan mitra Ibu Hj. Rafidah Yuda selaku Ketua Panti Asuhan Aisyiyah Cabang Koto Tangah Koto Padang. Pada tahap ini penjelasan yang berhubungan dengan pelaksanaan program, seperti sosialisasi berkaitan dengan bahan-bahan perjernih air yang alami dan buatan. Tahap pelaksanaan, pelaksanaan program sesuai dengan kesepakatan bersama antara tim PPM UM Sumbar dengan 
mitra. Pada tahapan ini dihadiri oleh ketua Pantia Asuhan Putri Aisyiyah Cabang Koto Tangah dalam penjelasan ini dilakukan diskusi untuk kelancaran kegiatan baik sosialisasi dan praktek pembuatan alat penjernih air. Diskusi tentang kegiatan sosialisasi yang disepakati bersama bahwa kegiatan PPM ini akan diadakan di lokasi Panti yaitu di ruangan Mushala dengan mematuhi aturan protokol kesehatan dalam melaksanakan acara pengabdian nantinya, ini digambarkan pada Gambar 5 dibawah ini.
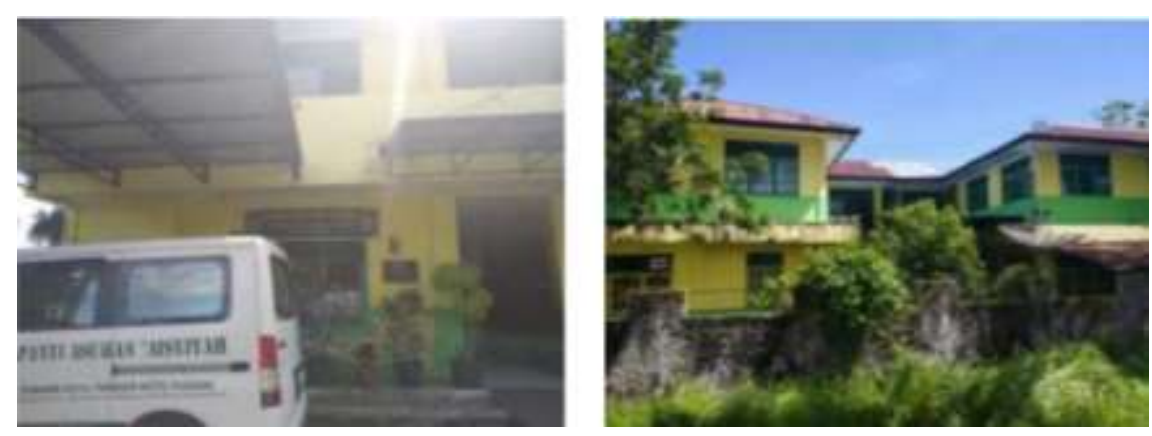

Gambar 5. Gedung Panti Asuhan Putri Aisyiyah Putri Cabang Koto Tangah

\section{Tahap sosialisasi}

Sosialisasi dilaksanakan di ruangan mushala Panti Asuhan Aisyiyah Cabang Koto Tangah Kota Padang. Sebelum penyampaian materi sosialisasi, anak-anak panti yang masih duduk dibangku SMP dan SMA sebanyak 13 orang tersebut mengisi kuisioner untuk mengukur seberapa banyak pengetahuan mereka tentang jenis-jenis bahan penjernih air alami dan buatan serta metode penjernihan air secara sederhana. Hasil kuisioner mereka dapat dilihat pada Gambar 6 berikut :

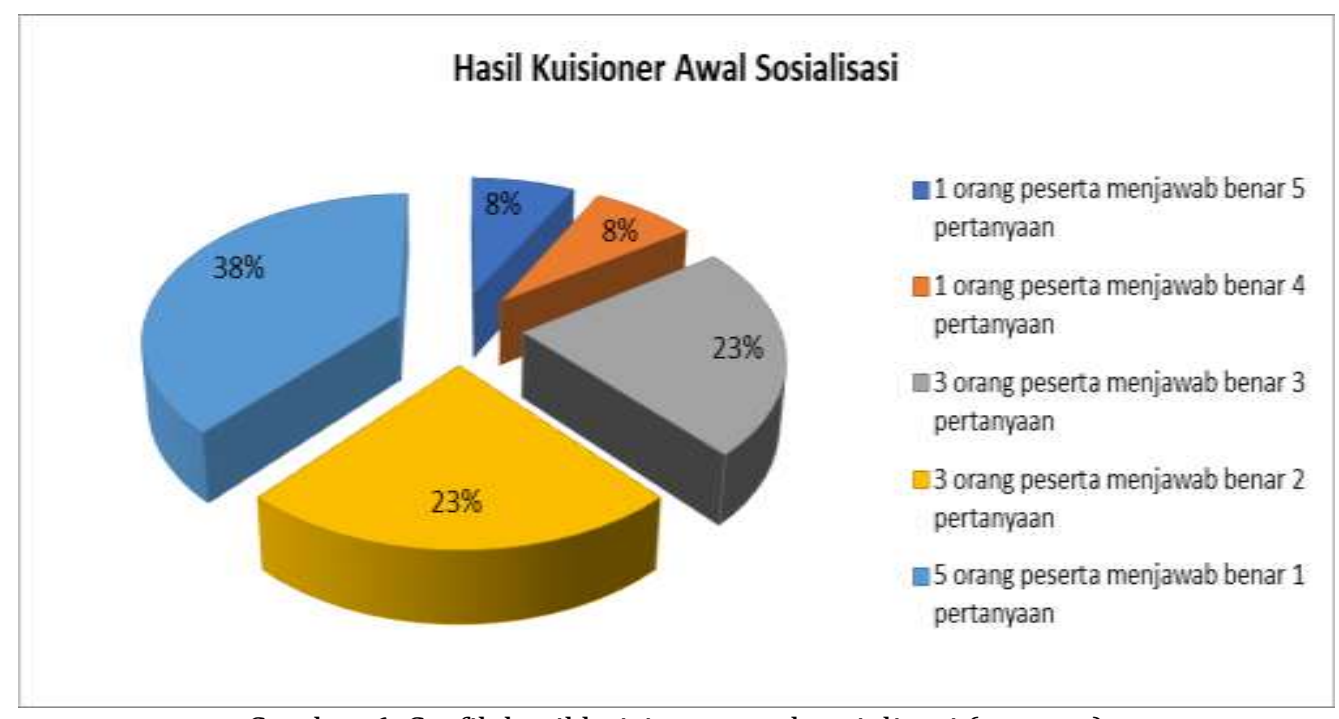

Gambar 6. Grafik hasil kuisioner awal sosialisasi (pre-test)

Dari gambar 6 dapat dilihat bahwa hasil kuisioner awal sosialisasi (pre-test) sebanyak $38 \%$ peserta menjawab benar 1 pertanyaan, $23 \%$ peserta menjawab benar 2 pertanyaan dan 3 pertanyaan, terakhir $8 \%$ peserta menjawab benar 1 dan 2 pertanyaan. Dapat juga kita simpulkan bahwa tingkat pengtehuan mereka tentang air bersih dan metoda penjernihan air masih kurang. 


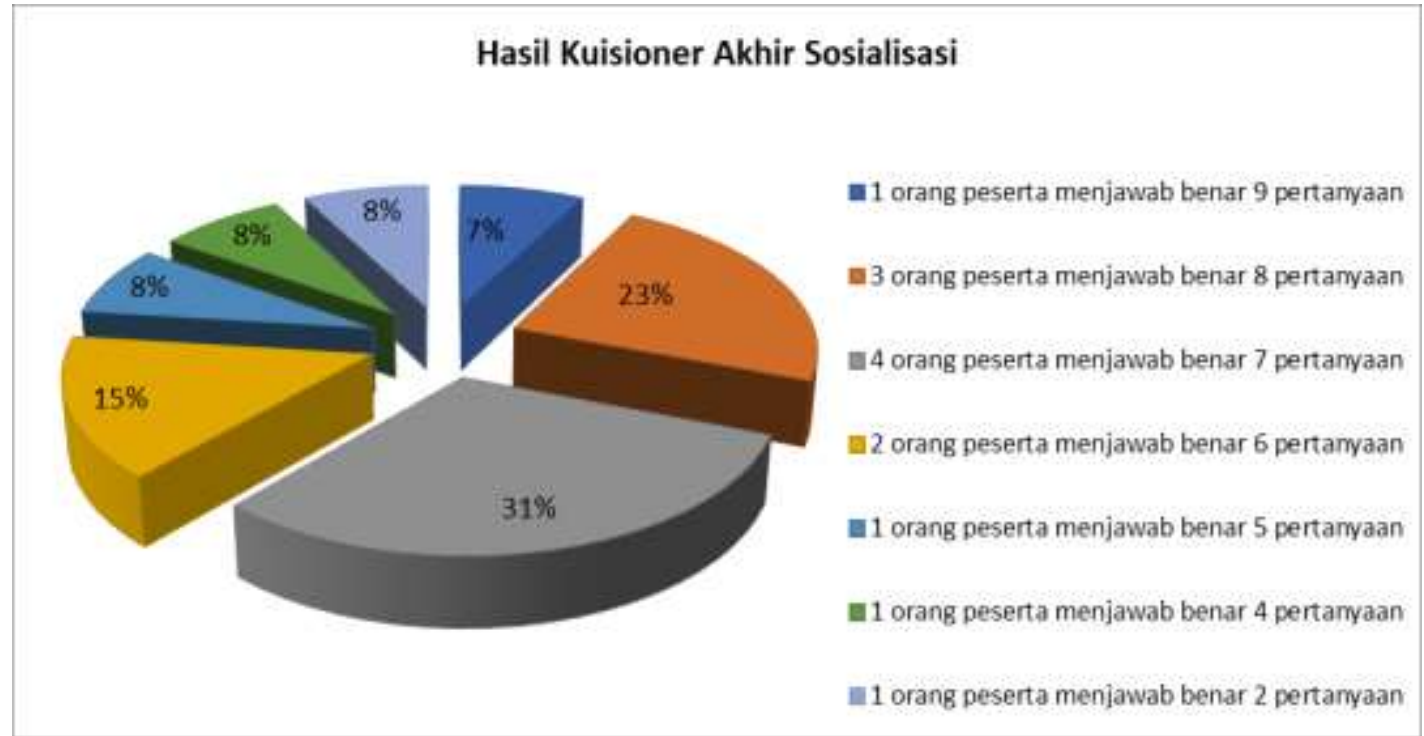

Gambar 7. Grafik hasil kuisioner akhir sosialisasi (post-test)

Dari gambar 7 dapat dilihat bahwa 31\% (4 orang) menjawab 7 pertanyaan yang benar, $23 \%$ (3 orang) menjawab 8 pertanyaan yang benar, 15\% (2 orang) menjawab 6 pertanyaan yang benar, 8\% (1 orang) menjawab pertanyaan 5, 4, dan 2 yang benar, terakhir $7 \%$ menjawab 1 pertanyaan 9 pertanyaan yang benar.

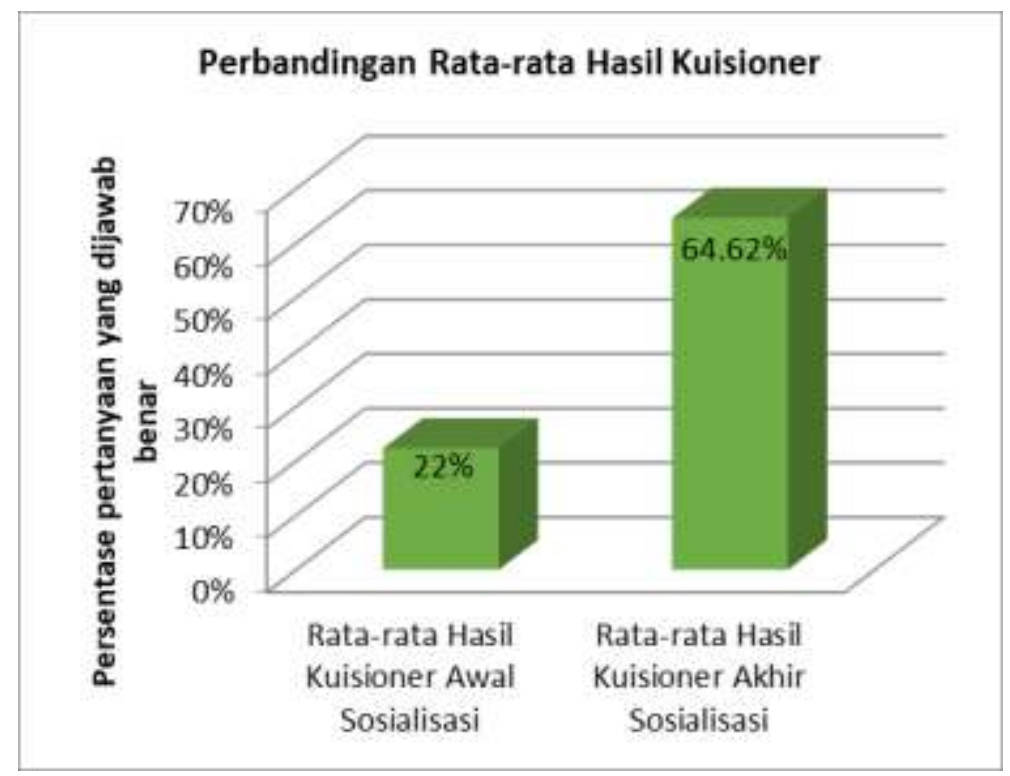

Gambar 8. Grafik Perbandingan Rata-rata Hasil Kuisioner

Pada gambar 8 dapat kita lihat, kenaikan rata-rata hasil kuisioner awal dan akhir sosialisasi dari $22 \%$ meningkat menjadi $64,62 \%$.

Adapun serba serbi kegiatan sosialisasi di kelompok Panti Asuhan Aisyiyah Cabang Koto Tangah ini bisa kita lihat pada Gambar 10 dibawah ini. 


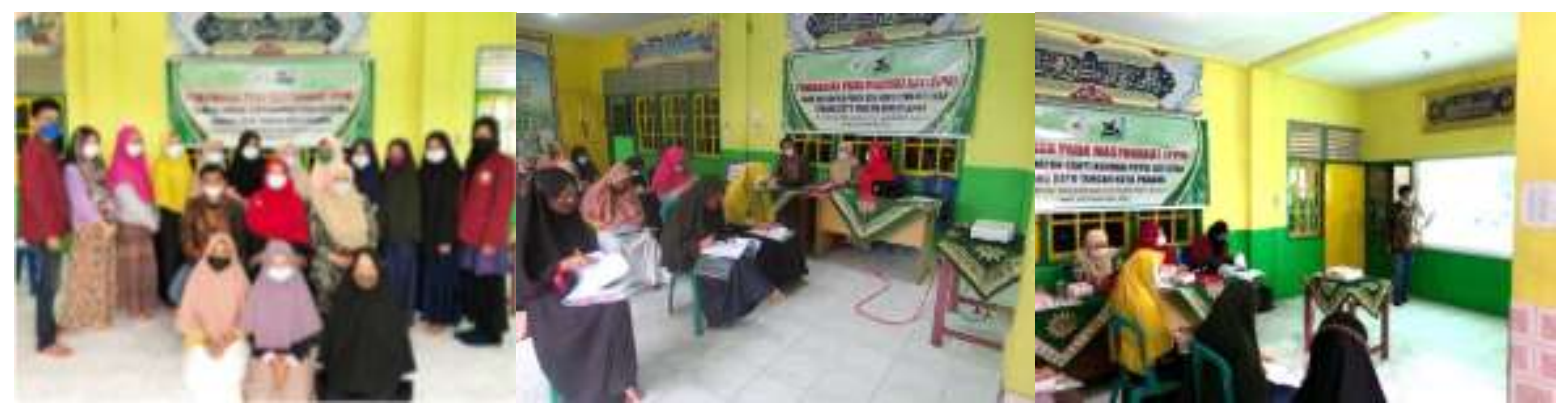

Gambar 9. Serba-serbi kegiatan sosialisasi

\section{Tahap Sosialisasi Pembuatan Alat Penjernihan Air}

Kegiatan selanjutnya adalah sosialisasi pembuatan alat penjernih air yang dilakukan pada bulan Agustus 2021 di Panti Asuhan Aisyiyah Cabang Koto Tangah Kota Padang. Adapun tahap dalam sosialisasi pembuatan alat penjernih air bersih dimulai dari yaitu :

a. Kegiatan pencucian bahan yang akan digunakan untuk penjernih air yaitu : pasir, kerikil, ijuk, dan arang tempurung kelapa yang dapat dilihat pada Gambar 11.
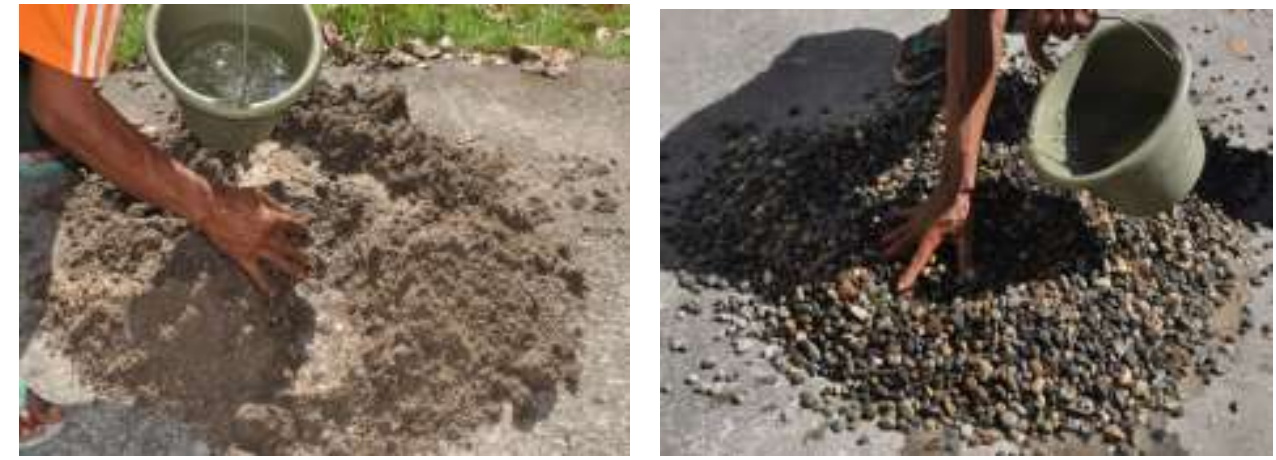

Gambar 10. Proses Pencucian bahan penjernih air (pasir dan kerikil)

b. Melubangi PVC dengan jarak $5 \mathrm{~cm}$ dari bawah permukaan dan pemasangan kran.
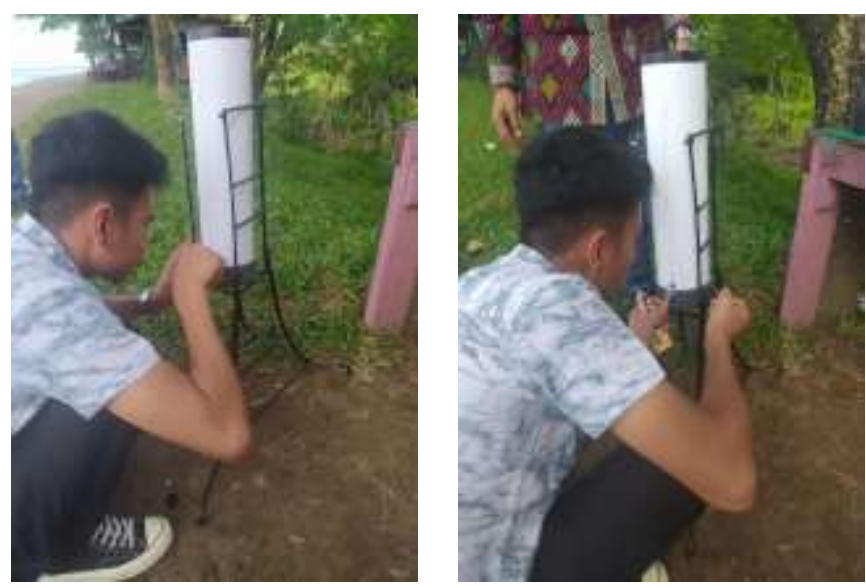

Gambar 11. Proses melubangi PVC dan pemasangan kran

c. Pembuatan tempat peninggi alat yang terbuat dari besi, dimana PVC tersebut diletakkan yang lebih tinggi, untuk memudahkan menampung air yang sudah disaring 


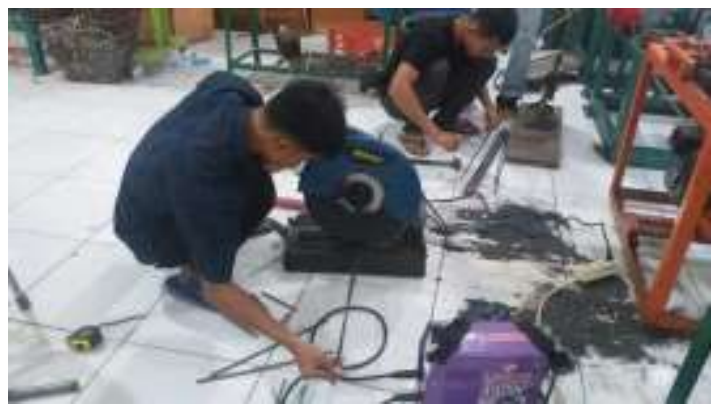

Gambar 12. Proses pembuatan peninggi alat

d. Pengukuran PVC untuk mengisi bahan-bahan penjernih air yang sudah dicuci dan dikeringkan sesuai dengan urutan yang ditentukan

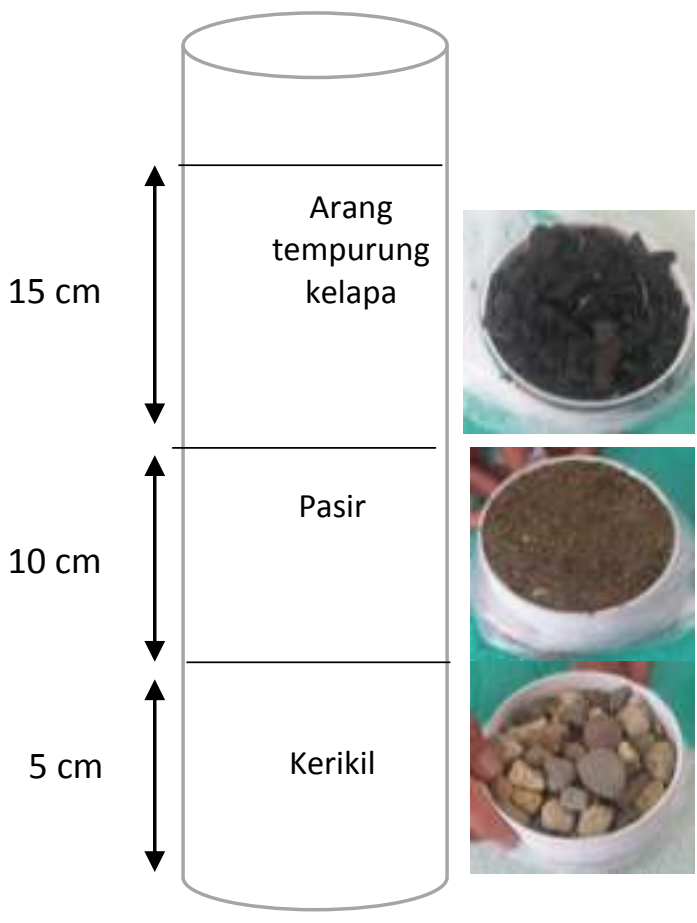

Gambar 13. Bahan penjernih air dan tinggi bahan dalam pipa PVC

e. Membandingkan Air yang sudah disaring dengan air yang belum disaring

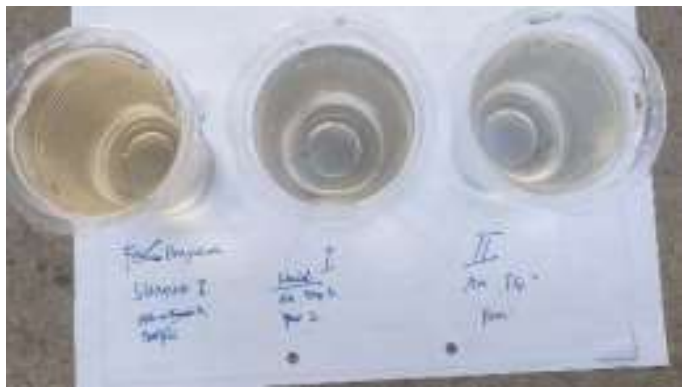

Gambar 15. Perbandingan Air yang Belum Disaring dan Setelah Disaring

Salah satu solusi untuk menghilangkan bau dan rasa pada air adalah dengan menggunakan arang tempurung kelapa. Karbon aktif atau arang aktif yang kita dapatkan dari arang batok kelapa adalah jenis karbon yang memiliki luas permukaan yang besar sehingga 
dapat menyerap kotoran dalam air. Alat penyaring membantu proses penyaringan. Penggunaan alat didasarkan kepada jenis cara penyaringan. Dari praktek pembuatan alat penjernihan air, didapatkan bahwa terdapat perubahan warna air yang semula keruh menjadi jernih, dan perubahan bau air yang semula berbau menyengat menjadi tidak berbau (Earnestly, Suryani, Firdaus, \& Yermadona, 2019). Penjernihan air dapat dilakukan secara sederhana tanpa menggunakan peralatan mahal, dan menggunakan peralatan yang mudah didapatkan di lingkungan sekitar masyarakat (Wahyuni, Sari, \& Afidah, 2017) . Ada yang menggunakan drum, bambu, dan alat-alat yang mudah ditemukan disekitar kita.

\section{KESIMPULAN}

Berdasarkan pelaksanaan pengabdian kepada masyarakat yang sudah dilakukan dapat disimpulkan:

1. Kegiatan Pengabdian Pada Masyarakat yang dilaksanakan di Panti Asuhan Aisyiyah Putri Cabang Koto Tangah Kota Padang berjalan lancar dan adanya komunikasi yang baik antara anak-anak panti yang menjadi peserta dengan tim pengabdian.

2. Kegiatan PPM ini meningkatkan pengetahuan masyarakat tentang bahan penjernih air secara alami maupun buatan yang dibuktikan dengan rata-rata hasil kuisioner awal sosialisasi (pretest) $22 \%$ dan rata-rata hasil kuisioner akhir sosialisasi (post-test) 64,62 \%.

3. Dari pembuatan alat penjernihan air, didapatkan bahwa terdapat perubahan warna air yang semula keruh menjadi jernih, dan perubahan bau air yang semula berbau menjadi tidak berbau.

\section{UCAPAN TERIMA KASIH}

Penulis mengucapkan terima kasih kepada Lembaga Penelitian dan Pengabdian Pada Masyarakat Universitas Muhammadiyah Sumatera Barat yang telah memberi dukungan financial terhadap pengabdian ini.

\section{DAFTAR PUSTAKA}

Annisa. (2017). Sistem Pendidikan Anak Dalam Panti Asuhan Aisyiyah Cabang Koto Tangah Kota Padang. Padang.

Earnestly, F. (2018a). Analisa Suhu, pH dan Kandungan Logam Besi Pada Sumber Air Tanah di Kampus Universitas Muhammadiyah Sumatera Barat (UMSB) Padang. Menara Ilmu, XII(79), 201-205.

Earnestly, F. (2018b). Analisis Kadar Klorida, Amoniak di Sumber Air Tanah Universitas Muhammadiyah Sumbar Padang. Katalisator, 3(2), 89-95.

Earnestly, F., Suryani, Firdaus, \& Yermadona, H. (2019). Penjernihan air di RT 001 RW 013 Kelurahan Pasie Nan Tigo. DINAMISIA Jurnal Pengabdian Kepada Masyarakat, 03 (Special Issue), 101-109.

Indonesia, M. K. R. (2017). Peraturan Menteri Kesehatan Republik Indonesia Nomor 32 Tahun 2017 Tentang Standar Baku Mutu Kesehatan Lingkungan dan Persyaratan Kesehatan Air Untuk Keperluan Higiene Sanitasi, Kolam Renang, Solus Per Aqua, dan Pemandian Umum. In Peraturan Menteri kesehatan Republik Indonesia.

Kusumaningrum, W., \& Nurhayati, I. (2016). Penggunaan Karbon Aktif Dari Ampas Tebu Sebagai Media Adsorbsi Untuk Menurunkan Kadar Fe (Besi) dan Mn (Mangan Pada Air Sumur Gali di desa Gelam Candi. Jurnal Teknik Waktu, 14(416), 1-7.

Nakoe, R., S Lalu, N. A., \& Mohamad, Y. A. (2020). Perbedaan Efektivitas Hand-Sanitizer Dengan Cuci Tangan Menggunakan Sabun Sebagai Bentuk Pencegahan Covid-19. Jambura Journal of Health Sciences and Research, 2(2), 65-70. https://doi.org/10.35971/jjhsr.v2i2.6563

RI, K. K. (2014). Profil Kesehatan Indonesia 2014. Jakarta: Kementrian Kesehatan Republik 
Indonesia.

Sitompul, E. P. J. M. T. (2018). Pengolahan Air Bersih di Pondok Pesantren As-Shiddiqiyyah dan Panti Asuhan Al-Haq Kecamatan Sungai Kakap Kabupaten Kubu Raya. Al-Khidmah, 1, 1723. https://doi.org/10.1007/s00726-013-1492-2

Wahyuni, S., Sari, M., \& Afidah, M. (2017). Sosialisasi dan Pelatihan Teknik Penyaringan Air Desa Mengkapan, Siak. Dinamisia-Jurnal Pengabdian Kepada Masyarakat, 1(1), 100-105.

Yunike, Erna Juita, \& Farida. (2016). Studi Tentang Kualitas Air Tanah Dangkal di Daerah Pemukiman Penduduk di Pantai Pasir Jambak Kelurahan Pasie Nan Tigo Kecamatan Koto Tangah Kota Padang. Jurnal Ilmiah Mahasiswa STKIP PGRI Sumatera Barat. https://doi.org/10.1192/bjp.112.483.211-a 